\title{
David French, The British Way in Counter-Insurgency, 1945- 1967, Oxford University Press, 2011, ss. 352
}

Już od niemal roku w sprzedaży znajduje się wyjątkowa publikacja The British Way in Counter-Insurgency, 1945-1967, szczególnie istotna z punktu widzenia badań nad schyłkiem imperialnej potęgi Wilekiej Brytanii. Jej autorem jest profesor David French z University College London (od 2008 roku Emeritus), jeden z najlepszych specjalistów zajmujących się problematyką związaną z Armią Brytyjską od połowy XIX wieku do czasów współczesnych. Jego prace cechuje dogłębna analiza funkcjonowania najważniejszych mechanizmów Brytyjskich Sił Zbrojnych. Publikacje autorstwa prof. D. Frencha spotykają się z dużym uznaniem środowiska historyków wojskowości, czego dowodem jest między innymi nagroda Arthura Goodzeita, którą otrzymał za pracę pod tytułem Doctrine and Organisation in the British Army, 1919-1932' oraz Medal Templera za Military Identities: the Regimental System, the British Army and the British People c 1870-2000². Oprócz wojskowości, zainteresowania Autora dotyczą również zagadnień związanych z historią dyplomacji i polityką zagraniczną Wielkiej Brytanii.

Recenzowana książka obejmuje okres od zakończenia II Wojny Światowej do 1967 roku. Dla Wielkiej Brytanii jest to kluczowy okres transformacji imperium, którego jednym z głównych przejawów była dekolonizacja czy też systematyczne ograniczanie zakresu i wielkości terytoriów zamorskich. Jednym z głównych powodów takiego stanu rzeczy była postępująca wielowymiarowa erozja imperium, na skutek coraz gorszej kondycji ekonomicznej państwa.

Tematyka działań przeciwpartyzanckich i wszelkiego rodzaju przejawy walki zbrojnej, mieszczące się $\mathrm{w}$ ramach pojęcia konfliktu asymetrycznego stanowią, zwłaszcza w ostatnich latach, przedmiot szczególnego zainteresowania badaczy i decydentów cywilnych i wojskowych. Są one spowodowane obecnymi wyzwaniami, jakie stają przed krajami realizującymi misje stabilizacyjne w Iraku czy w Afganistanie. W dalszym ciągu poszukiwane są rozwiązania, metody i strategie, które umożliwiłyby uzyskanie względnej stabilizacji i wyznaczenie kierunku postępowania w tego rodzaju konfliktach. Zarówno w dyskursie naukowym, jak i literaturze przedmiotu, funkcjonuje pogląd wskazujący, że we współczesnych konfliktach jedynie Brytyjczykom udało się odnieść sukces w tej materii, między innymi w oparciu o operacje przeciwpartyzanckie na Malajach w latach 50. i 60. XX w. Co więcej, sami Brytyjczycy już w XXI wieku, przygotowując się do interwencji w Iraku i Afganistanie, głęboko wierzyli w to, że posiadają ta-

1 D. French, Doctrine and Organisation in the British Army, 1919-1932, Oxford University Press 2000.

2 D. French, Military Identities: the Regimental System, the British Army and the British People c 1870-2000, Oxford University Press 2005. 
kowe umiejętności, o czym we wstępie wspomina D. French. Autor powołuje się także na fundamentalne dzieło Sir Roberta Thompsona pt. Defeating Communist Insurgency ${ }^{3}$, opublikowane w 1966 roku, które w wielu środowiskach uważane było za uniwersalną receptę na sukces $\mathrm{w}$ walce $\mathrm{z}$ partyzantami.

Po analizie tych poglądów D. French opracował zestaw założeń i mechanizmów, które określił mianem idealnych, brytyjskich działań przeciwpartyzanckich. Do najważniejszych z nich należy zaliczyć konieczność koordynacji działań na poziomie administracji rządowej (współpraca międzyresortowa), zwalczania źródeł i przyczyn szeroko rozumianej działalności wywrotowej, a nie partyzantów samych w sobie, postępowanie zgodnie z prawem przy użyciu minimalnej siły, utworzenie rozwiniętej sieci informacyjnej, a także uzyskanie zwycięstwa na poziomie politycznym. Głównym celem pracy D. Frencha jest odpowiedź na pytanie: w jakim zakresie brytyjscy żołnierze, funkcjonariusze oraz politycy stosowali się do przytoczonych powyżej założeń w trakcie realizowania misji przeciwpartyzanckich w latach 1947-1967?. We wstępie, oprócz jasno zarysowanej problematyki i celów badawczych, znajdziemy także wiele ciekawych uwag odnośnie terminologii i przede wszystkim stanu badań. Autor wyraźnie podkreśla fakt, że precyzyjne opracowanie tematu jest możliwe tylko i wyłącznie w sytuacji, kiedy do problemu podchodzi się całościowo. Opisywanie poszczególnych operacji, które oderwane są od historycznej rzeczywistości, uniemożliwia uzyskanie pełnego obrazu sytuacji. Najważniejszym sformułowaniem jest jednak deklaracja autora, że książka absolutnie nie odpowiada na pytania, jak rozwiązywać współczesne problemy. Oczywiście podkreśla ogromną wartości badań historycznych, a także mądrości, która z nich płynie. Jednak zdecydowanie stwierdza, że nie mogą one stanowić zbioru gotowych rozwiązań dla aktualnych dylematów.

Imponująco przedstawia się bibliografia, zwłaszcza obszerny materiał archiwalny. Po krótkiej analizie widać, że Autor dokonał dogłębnej kwerendy zarówno dokumentów, jak również nagrań i wspomnień uczestników wydarzeń.

Rozdział pierwszy The Colonial State przedstawia czytelnikom strukturę brytyjskich posiadłości zamorskich, począwszy od warstwy organizacyjnej (wskazując np. różnice pomiędzy kolonią a protektoratem i zależnością poszczególnych struktur administracyjnych od Colonial Office). Przedstawienie administracyjnych detali jest bardzo istotne, szczególnie dla badania procesów decyzyjnych związanych z operacjami reagowania kryzysowego w rożnych częściach świata. W książce najwięcej miejsca poświęcono przedstawieniu działań w Kenii, Palestynie, Niasie, na Malajach, w Adenie, Gujanie Brytyjskiej, Strefie Kanału Sueskiego oraz Cyprze. Mamy więc do czynienia zarówno z koloniami Korony Brytyjskiej, protektoratami, terytoriami zależnymi lub obszarami trudnymi do zdefiniowania (Strefa Kanału Sueskiego). W swojej analizie D. French opisuje

3 R. Thompson, Defeating Communist Insurgency. The lessons of Malaya and Vietnam, Różne wydania, pierwsze 1966. 
także strukturę oraz wyposażenie oddziałów i poddziałów policyjnych, żandarmeryjnych $^{4} \mathrm{i}$ wojskowych odpowiedzialnych za bezpieczeństwo i porządek w rejonach brytyjskiego zaangażowania. Na wszystkich opisywanych terenach pojawiał się ten sam problem. Był on związany z brakiem środków do utrzymywania sprawnych struktur, które umożliwiałyby prowadzenie działań profilaktycznych oraz prewencyjnych. Autor podaje przykład Niasy, gdzie jeden brytyjski policjant i 15 afrykańskich funkcjonariuszy przypadało na 100000 obywateli (s. 16). Należy podkreślić, że wszystkie przedstawiane informacje są podparte przypisami, odsyłającymi do materiału źródłowego, wspomnień lub dokumentów. Niemal na każdej stronie znajduje się co najmniej kilka odniesień, głównie do zasobów National Archives. Bardzo łatwo dostrzec doskonałe rozeznanie Autora w materiale archiwalnym, bowiem przywołane dokumenty pochodzą z bardzo zróżnicowanych zespołów. Autor w swoim wywodzie wykorzystuje memoranda z narad Cabinet Office, jak również taktyczne i operacyjne dyskusje zawarte w korespondencji pomiędzy kadrą kierowniczą Sił Zbrojnych Wielkiej Brytanii a dowódcami komponentów, zarchiwizowane i zlokalizowane w zespołach archiwalnych War Office. Jednak najwięcej materiałów opatrzonych jest sygnaturą zaczynającą się od liter CO, czyli Colonial Office, co jest oczywiście w pełni zrozumiałe. Należy szczególnie podkreślić ogromną zręczność Autora w zakresie wkomponowywania cytatów do tekstu, dzięki czemu książka jest nie tylko bardzo ciekawa, ale również doskonale się ją czyta.

W dalszej części D. French przedstawia różne mechanizmy i koncepcje organizacyjne, mające na celu zapewnienie bezpieczeństwa. Jednym z opisywanych sposobów była koordynacja działań i tworzenia komisji czy też zespołów składających się z przedstawicieli wojska, lokalnej policji oraz przedstawicieli służb wywiadu i kontrwywiadu, działających na danym obszarze. W książce zawarte są informacje na temat sytuacji, jaka miała miejsce w poszczególnych regionach. Najciekawiej przedstawiają się doniesienia o ogromnych kłopotach w znalezieniu tłumaczy, współpracowników, agentów etc., co paraliżowało funkcjonowanie systemu. Przedstawiony został także mechanizm finansowania podmiotów odpowiedzialnych za bezpieczeństwo. W pierwszym rozdziale czytelnik będzie w stanie zweryfikować swoje poglądy odnośnie poziomu wyszkolenia i stopnia zaangażowania Armii Brytyjskiej w operacje przeciwpartyzanckie. Znajdziemy też ogólną informacje, że ilość żołnierzy stacjonujących na terytoriach zamorskich była zbyt mała do realizacji powierzonych zadań. D. French podaje, że w 1951 roku spośród 429000 brytyjskich żołnierzy służacych w Brytyjskich Siłach Zbrojnych 244000 stacjonowato na wyspach, $63000 w$ RFN i jedynie $45000 w$ Strefie Kanatu Suezkiego, 35000 na Malajach (s. 33). Jednym z przejawów zbyt małej obsady etatowej były ograniczone możliwości, np. w obszarze szkolenia. Zdaniem

${ }^{4}$ Przykładem są np. zmotoryzowane oddziały Policji Palestyńskiej wyposażone i szkolone także jako jednostki lekkiej piechoty. 
Autora taka sytuacja była efektem zbyt małego potencjału militarnego Brytyjskiego Imperium. Liczba żotnierzy, która mogła zostać wysłana [na terytoria zależne] $i$ utrzymywana, była ograniczona ze względu na strategiczna konieczność utrzymywania dużych sit w Europie, niewielki potencjał ludzki w koloniach, oraz zróżnicowane problemy o charakterze politycznym. (s. 41). W tym miejscu zdecydowanie przydałaby się nieco szersza analiza zagadnienia uwzględniająca liczbę brytyjskich żołnierzy w poszczególnych regionach, skonfrontowana $\mathrm{z}$ analizami rzeczywistego zapotrzebowania sporządzonymi przez odpowiednie agendy. Dane przedstawione przez D. Frencha są bardzo ogólne. Należy pamiętać o ograniczonych możliwościach dostępu do tego rodzaju materiałów, jednak $\mathrm{z}$ dużą dozą prawdopodobieństwa można stwierdzić, że takie analizy z pewnością istniały.

W drugim rozdziale Gangsters, Thugs and Bandits D. French przedstawia i charakteryzuje wrogów Imperium. Z układu tekstu i sformułowań używanych przez Autora można stwierdzić, że jednym z podstawowych celów tej części jest zdecydowane zanegowanie popularnej tezy o walce Brytyjczyków z zalewającym kolonie komunizmem. Co ciekawe, D. French pokazuje, że błędny ogląd problemu mieli także niektórzy brytyjscy politycy, którzy wszędzie dostrzegali „macki komunistów”. Tymczasem w większości opisywanych przypadków głównym motywem działania był nacjonalizm, budowany na fundamencie niechęci do Brytyjczyków, rodzącej się w atmosferze biedy, głodu i braku perspektyw. Działania i organizacje, które można byłoby zdefiniować jako „komunistyczną partyzantkę”, funkcjonowały w zasadzie tylko na Malajach. Co więcej, nawet raporty żołnierzy napływające do Londynu wyraźnie podkreślały to, że bez znalezienia sposobu na wyeliminowanie nędzy, chorób, dysproporcji społecznych czy analfabetyzmu nie uda się wygrać konfrontacji. Kolejnym problemem, na który zawraca uwagę Autor, był zdecydowany opór Brytyjczyków względem próby rzeczywistej oceny oraz identyfikacji poczynań i motywów działań ,partyzantów”. D. French stwierdza: Brytyjczycy przekonani o moralnej stuszności swoich działań, realizowanych pod sztandarami idei imperialnych, zaliczali do kategorii przestępców wszystkich, którzy próbowali się im sprzeciwić (s. 73).

Trzeci rozdział The Legal Context and Counter-Insurgency by Committee poświęcony jest zagadnieniom prawnym sankcjonującym użycie siły, czy też prowadzenie działań bojowych na terytoriach zamorskich. Główny nacisk został położony na przedstawienie mechanizmu, dzięki któremu Brytyjczycy zdecydowali się pozostawić kierowanie operacjami w rękach cywilnej administracji, zorganizowanej w komitety. Rozdział zawiera analizę poszczególnych regulacji, ale także, co najważniejsze, przedstawia funkcjonowanie tych rozwiązań w praktyce, wskazując uchybienia i utrudnienia szczególnie w obszarze współpracy pomiędzy podmiotami lokalnymi a urzędnikami, żołnierzami i funkcjonariuszami reprezentującymi interesy Imperium. 
Czwarty rozdział zatytułowany Varieties of coercion: Exemplary Force, Counter - terrorism, and Population Control, poświęcony jest chyba najważniejszej, wykonawczej formie realizowanych działań. Podstawowym zadaniem Sił Bezpieczeństwa było zapewnienie obywateli o wysokim poziomie bezpieczeństwa, a także uświadomienie przeciwnika o nieuchronności konsekwencji w przypadku wystąpienia przeciwko władzy. Olbrzymią rolę odgrywało także karanie obywateli za współpracę z bandytami, którą powszechnie nazywano collective punishment. Kary te obejmowały przeszukania, masowe deportacje, zamykanie sklepów należących do nielojalnych obywateli czy wręcz wysadzenie budynków i wiosek. Jednym ze sposobów „ochrony” obywateli było przesiedlanie mieszkańców wiosek do ściśle chronionych, otoczonych drutem kolczastym osad, w których obywatele podlegali ścisłej kontroli, z reglamentacją żywności włączenie. W rozdziale znajduje się także opis metody działań przeciwpartyzanckich w wymiarze taktycznym i operacyjnym, realizowany przez różne podmioty. Autor prezentuje także bardzo ciekawe zestawienie liczby aresztowań na poszczególnych terytoriach, połączone $\mathrm{z}$ odniesieniem do populacji całkowitej regionu i liczby aresztowanych na 100.000 mieszkańców (s. 111). Wszystkie dane poparte są dokładnymi odniesieniami do dokumentów. Kolejna tabela przedstawia straty ludzkie ze strony Sił Bezpieczeństwa, partyzantów oraz ludności cywilnej. Elementem, którego wyraźnie brakuje jest zestawienie stanów liczbowych Sił Bezpieczeństwa na poszczególnych terytoriach. Stopień intensywności działań można przeanalizować dzięki tabeli przedstawiającej liczbę zabitych (żołnierzy i policjantów, partyzantów, cywili) podczas operacji realizowanych przez Brytyjczyków w różnych częściach świata w omawianym okresie. Według danych przedstawionych przez autora (s. 133), najwięcej strat Brytyjczycy ponieśli w konflikcie w Malezji, gdzie życie straciło 4134 żołnierzy i policjantów. Zdecydowanie najbardziej tragiczne działania były realizowane w Kenii, gdzie oprócz trudnej do oszacowania liczby zabitych rebeliantów (liczba waha się pomiędzy 10 a 20 tysięcy) życie straciło około 25000 cywili, przy brytyjskich stratach 1166 zabitych.

Rozdział piąty pod tytułem Britain's Dirty Wars?. Jego celem jest odpowiedź na pytanie, czy Brytyjczycy, realizując operacje przeciwpartyzanckie, posuwali się zbyt daleko, łamiąc prawa człowieka oraz brytyjskie ustawodawstwo. Rozdział rozpoczyna się od przedstawienia kilku przykładów wskazujących, że zdarzały się sytuacje, w których zarówno cywile, jak i partyzanci zostali niesłusznie poszkodowani. D. French zauważa, że wobec badania tego zagadnienia historyk zostaje postawiony wobec istotnego problemu, jakim jest obiektywna ocena sytuacji, w której potencjalny poszkodowany będzie skłonny do przerysowywania i wyolbrzymiania krzywd, podczas gdy funkcjonariusze policji i żołnierze solidarnie wypierać się będą wszelkich naruszeń regulaminu. Jednym ze źródeł, które D. French uznaje za wartościowe w procesie weryfikacji, są raporty Międzynarodowej Organizacji Pracy czy też Międzynarodowego Czerwonego Krzyża. Jednym z mierników przytaczanych przez Autora, w przypadku oceny prowadzo- 
nych działań, jest ilość sztuk broni palnej odnalezionej i zakfalifikowanej jako należąca do partyzantów, w stosunku do ilości zabitych, sklasyfikowanych jako partyzanci. W tym aspekcie D. French, powołując się na raport sporządzony przez analityków War Office, pokazuje, że w przypadku działań w Kenii w latach 1952-1955 na 8400 zabitych partyzantów (s. 153), odnaleziono zaledwie 1193 sztuki broni, co w oczywisty sposób wzbudza wątpliwość, czy aby wszystkie ofiary miały na sumieniu wspólpracę z partyzantami. W kategoriach Dirty War wpisany został także proceder okaleczania zwłok. W książce przedstawiony jest skandal wywołany przez publikację dziennika Daily Worker z 1952 roku, w której znalazło się zdjęcie żołnierza Brytyjskiej Piechoty Morskiej, trzymającego odciętą głowę partyzanta. Artykuł wywołał skandal i oburzenie wśród opinii publicznej (s.153). Reakcją na wydarzenia było wydanie całkowitego zakazu dokonywania tego typu aktów. Autor zawraca jednak uwagę, że obcinanie kończyn (palców u rąk lub całych dłoni) czy głów zmarłym ofiarom miewało także inny wymiar. W poszczególnych sytuacjach żołnierze odcinali palce lub głowy w celu dokonania identyfikacji ofiar (np. wówczas gdy niemożliwy był transport zwłok do miejsca, w którym identyfikacja mogłaby zostać dokonana). $\mathrm{W}$ rozdziale zostały także poruszone inne problemy, jak np. kwestia stosowania tortur podczas przesłuchań czy sprawa „szwadronów śmierci” Majora Roya Farrana w Palestynie.

Bardzo ważne miejsce w pracy zajmuje rozdział Winning Hearts and Minds. Wygrywanie, zdobywanie ludzkich serc jest pojęciem bardzo popularnym w odniesieniu do prowadzenia działań przeciwpartyzanckich. Uważa się, że to właśnie zapewnienie bezpieczeństwa ludności cywilnej, która odmawiając współpracy z partyzantami, przyczynia się do odniesienia zwycięstwa, jest jednym z najważniejszych elementów działań przeciwpartyzanckich. Obok ogólnej charakterystyki relacji „wyzwoliciele” - ludność cywilna w różnych rejonach, najciekawiej przedstawia się analiza zagadnienia pomocy materialnej, czy też projektów mających na celu rozwój infrastruktury (w tym rolnej), opieki zdrowotnej i szkolnictwa. D. French zwraca uwagę, że w świetle dokumentów w Colonial Office, wskutek ogólnego braku środków na prowadzenie działań przeciwpartyzanckich, pieniądze na ,projekty rozwojowe” były przekazywane na wydatki związane z realizowaniem zadań bojowych. Co więcej, z kwoty 1 mld funtów, które w latach 1946-1957 kolonie wydały na wyżej wymienione projekty, zaledwie 13,7 procent pochodziło z kieszeni brytyjskiego podatnika (na mocy Colonial Development and Welfare Act z 1945 roku) (s. 180), co w świetle szumnych koncepcji winning hearts and minds wydaje się zaskakująco niską kwotą. D. French postanowił także przeanalizować sprawę przesiedleń ludności do nowo zakładanych i pilnie strzeżonych wiosek. Zdaniem Autora zastosowane rozwiązania, oprócz mocno podkreślanych $w$ literaturze zalet o charakterze operacyjnym, miało także wiele wad. Zdaniem przesiedlanej ludności nowe miejsca zamieszkania częściej przypominały obozy koncentracyjne, aniżeli nowe miejsce do życia. Podsumowując 
rozdział, należy podkreślić, że Autor w sposób bardzo ciekawy przedstawił krytykę brytyjskich działań, które miały niewiele wspólnego ze wstępnymi i bardzo szlachetnymi w swojej wymowie założeniami.

Przedostatni rozdział Counter Insurgency an the Learning Curve, poświęcony jest wnioskom wyciągniętym $\mathrm{z}$ prowadzonych działań oraz ich implementacji w szkolnictwie wojskowym, przy opracowywaniu procedur i doktryn. D. French przedstawia pogłębioną analizę dokumentów, okólników, artykułów i podręczników, z której wynika, że to nie Sir Robert Thompson był autorem doktryny walki przeciwpartyzanckiej, lecz dokonał tylko kompilacji i opisu rozwiązań, które już wcześniej funkcjonowały w różnego rodzaju brytyjskich publikacjach resortowych.

Układ ostatniego rozdziału pracy pt. Problems of Sustainability można podzielić na dwie części. W pierwszej z nich otrzymujemy szeroki i bardzo ciekawy opis problemów funkcjonowania Imperium (głównie na terytoriach zależnych). Zaprezentowane zostały także podstawowe idee powojennej Wielkiej Brytanii, które rodziły się w głowach decydentów na Wyspach, ze szczególnym uwzględnieniem koncepcji transformacji Imperium, zmierzającej w kierunku tworzenia wspólnoty narodów. Trzonem tych założeń miało być doprowadzenie do uzyskiwania niepodległości przez dotychczasowe kolonie i terytoria zależne, przy jednoczesnym popieraniu lokalnych polityków, którzy wyrażali chęć utrzymywania bliskich stosunków z Wielką Brytanią. W odniesieniu do dekolonizacji funkcjonowała także koncepcja tworzenia federacji, czego przykładem było choćby utworzenie Federacji Malezji. Można odnieść wrażenie, że fragmenty te bardziej pasują do początkowej niż do końcowej części książki. Najciekawszym fragmentem drugiej części rozdziału jest analiza przedstawiająca, dlaczego brytyjskie działania przeciwpartyzanckie przyniosły efekty w Malezji, a nie w Adenie. D. French jednoznacznie przedstawia pogląd, że taki stan rzeczy wynikał ze zróżnicowanych uwarunkowań o charakterze geopolitycznym i społecznym, a nie z faktu zastosowania wyjątkowej taktyki.

Zakończeniem książki jest zwięzłe podsumowanie rozważań i próba odpowiedzi na kluczowe pytania postawione we wstępie. Autor wyraźnie podkreśla, że historia brytyjskich działań przeciwpartyzanckich to temat słabo zbadany. Efektem tego jest wiele poglądów funkcjonujących w dyskursie publicznym, które w żaden sposób nie odzwierciedlają rzeczywistości. D. French wyraźnie poddaje w wątpliwość zasadność i wartość strategii sformułowanej przed laty przez Sir Roberta Thomsona. Podkreśla także, że wspaniałe założenia kryjące się pod hasłem winning hearts and minds $\mathrm{w}$ dużej mierze pozostawały w sferze założeń.

Podsumowując, należy uznać, że książka ta stanowi ogromny wkład w badania nad historią Imperium Brytyjskiego. Zawarte w niej informacje pozwalają na prześledzenie i zrozumienie kluczowych wydarzeń i procesów w okresie dekolonizacji. D. French dzięki obszernej kwerendzie źródłowej zweryfikował też wiele poglądów odnośnie brytyjskich działań w koloniach, które w istocie prezentują 
się inaczej niż zakładało to wielu badaczy, a nawet twórców strategii działań przeciwpartyzanckich, takich m.in. jak Sir Robert Thompson. Należy podkreślić, że książka jest nie tylko doskonałym źródłem informacji odnośnie koncepcji i metod realizowania misji i zadań przeciwpartyzanckich. Jej niewątpliwą zaletę stanowi także dobrze przedstawiona sytuacja Brytyjczyków na terytoriach zależnych, którą można postrzegać jako jeden z symptomów postępującego rozkładu Imperium. Wszystkie powyższe czynniki powodują, że publikację D. Frencha należy traktować jako pozycję obowiązkową dla badaczy dziejów Imperium Brytyjskiego po 1945 roku. Publikacja ma także wartość dydaktyczną w kontekście krytycznej pracy ze źródłem. Jedynym minusem książki, patrząc z polskiej perspektywy jest cena (125\$), co z pewnością może ograniczać jej dostępność w Polsce.

\author{
Maciej Stanecki \\ Instytut Historyczny \\ Uniwersytet Warszawski
}

\begin{abstract}
Peter Hopkirk, Wielka gra. Sekretna wojna o Azje Środkowa, Zysk i S-ka Wydawnictwo, Poznań 2011, ss. 718 (tytuł oryginału The Great Game. On the Secret Service In High Asia, 1990, 2006)
\end{abstract}

$\mathrm{Z}$ zadowoleniem należy odnotować pojawienie się na polskim rynku wydawniczym książki Petera Hopkirka Wielka gra. Sekretna wojna o Azje Środkowa książki. Jest to tłumaczenie i od razu trzeba wyrazić żal, że tak wiele lat minęło od pierwszego wydania tej pracy w języku angielskim, i że jest to dopiero druga książka tego autora przełożona na język polski ${ }^{1}$.

Peter Hopkirk to Brytyjczyk, którego życiorysem można by obdzielić kilka osób. Zanim zajął się pisarstwem, Hopkirk był wojskowym - służył jako młodszy oficer w King's African Rifles. Później zajął się dziennikarstwem - między innymi pracował dla Independence Television News i przez prawie dwadzieścia lat dla „The Time”. Podróżował po krajach i regionach, o których później pisał w swoich książkach. Był między innymi w Rosji, Chinach, Indiach, Pakistanie, Iranie, Turcji, a także w Azji Centralnej i na Kaukazie. Doświadczył również niebezpiecznych chwil - został zatrzymany, podejrzany o szpiegostwo, przez tajne służby na Kubie, a także znalazł się na pokładzie samolotu porwanego przez arabskich terrorystów podczas lotu z Bejrutu.

1 Pierwszą była książka zatytułowana Obce diabły na Jedwabnym Szlaku: w poszukiwaniu zaginionych miast i skarbów w chińskiej części Azji Środkowej (Wydawnictwo Akademickie Dialog, Warszawa 2008). 